DOI: https://doi.org/10.24127/ajpm.v9i2.2722

\title{
PENGARUH KECERDASAN MATEMATIS-LOGIS DAN KEMANDIRIAN BELAJAR TERHADAP HASIL BELAJAR MATEMATIKA
}

\author{
Teguh Santoso ${ }^{1}$, Dwi Priyo Utomo ${ }^{2}$ \\ ${ }^{1,2}$,Magister Pendidikan Matematika, Universitas Muhammadiyah Malang, Indonesia \\ E-mail: $\quad$ teguhsantosoumm@gmail.com ${ }^{1)}$ \\ dwi_priyo@umm.ac.id ${ }^{2)}$
}

Received 13 March 2020; Received in revised form 28 June 2020; Accepted 29 June 2020

\begin{abstract}
Abstrak
Tujuan penelitian ini adalah untuk mengetahui pengaruh positif kecerdasan matematis logis dan kemandirian belajar terhadap hasil belajar matematika. Penelitian ini menggunakan pendekatan kuantitatif, dengan rancangan korelasional jenis penelitian expost facto. Pengambilan sampel dalam penelitian ini dilakukan dengan proportional random sampling. Teknik pengumpulan data dalam penelitian ini adalah angket dan tes. Lembar angket yang digunakan dalam penelitian ini terbagi menjadi dua, yaitu lembar angket kecerdasan matematis-logis dan lembar angket kemandirian belajar. Tes digunakan mendapatkan data hasil belajar matematika. Teknik analisis data menggunakan uji-F. Hasil analisis data penelitian menunjukkan bahwa kecerdasan matematis-logis secara parsial tidak ada pengaruh yang signifikan terhadap hasil belajar siswa. Kemandirian belajar siswa juga secara parsial tidak ada pengaruh yang signifikan terhadap hasil belajar matematika. Tidak ada pangaruh kecerdasan matematis logis dan kemandirian belajar terhadap hasil belajar matematika.
\end{abstract}

Kata kunci: Matematis-logis; kemandirian belajar; hasil belajar.

\begin{abstract}
The purpose of this study was to determine the positive influence of mathematical-logical intelligence and learning independence on mathematics learning outcomes. This research uses a quantitative approach, with a correlational design of ex post facto research. Sampling in this study was carried out by proportional random sampling. Data collection techniques in this study were questionnaire and test. The questionnaire sheet used in this study was divided into two, namely the mathematical-logical intelligence questionnaire sheet and the learning independence questionnaire sheet. The test is used to get data on learning outcomes in mathematics. Data analysis techniques using the F-test. The results of the analysis of research data indicate that mathematical-logical intelligence partially has no significant effect on student learning outcomes. Student learning independence is also partially there is no significant effect on mathematics learning outcomes. There is no effect of logical-mathematical intelligence and learning independence on mathematics learning outcomes.
\end{abstract}

Keywords: Mathematical-logical; learning independence; learning outcomes.

\section{PENDAHULUAN}

Jenjang pendidikan SMA atau yang sederajat merupakan tingkatan akhir proses pembelajaran menuju perguruan tinggi. Matematika adalah ilmu pengetahuan yang mempunyai peranan penting dalam berbagai disiplin ilmu di SMA (Bungsu, Vilardi, Akbar, \& Bernard, 2018). Lebih dari itu, matematika adalah salah satu disiplin ilmu yang paling objektif, logis, dan praktis (Lai, Zhu, Chen, \& Li, 2015). Matematika perlu diberikan kepada semua siswa untuk meningkatkan dalam kemampuan berpikir logis, sistematis, kritis dan kreatif. Kecerdasan matematis-logis erat kaitannya dengan matematika (Supardi, 2014). Matematika berbicara tentang bagaimana menemukan jawaban terbaik 
dari pertanyaan ke dalam pernyataan matematika (Sumantri \& Satriani, 2016).

Siswa yang memiliki kecerdasan matematis-logis yang tinggi cenderung bisa memahami suatu masalah dan menganalisa, serta dapat menyelesaikan dengan tepat. Kecerdasan matematislogis merupakan gabungan dari kemampuan berhitung dan kemampuan logika (Supardi, 2014; Suhendri, 2012). Kecerdasan matematis-logis adalah suatu kecerdasan yang meliputi kemampuan berfikir secara logis, menjelaskan secara matematis, dan berfikir secara deduktif dan induktif (Triwinarni, Fauzi, \& Monawati, 2017).

Sedangkan menurut menurut Zulfairanatama \& Hadi (2013) kecerdasan logika matematika merupakan kemampuan yang berhubungan dengan rangkaian alasan, aturan, dan mengenal pola-pola matematika.

Pada zaman sekarang ini sumber belajar sumber belajar dapat dicari dengan mudah, dan tidak hanya berpusat kepada guru. Oleh karena itu, kemandirian belajar siswa sangat penting untuk kegiatan belajar matematika. Kemandirian belajar adalah unsur yang penting dalam belajar matematika (Ningsih, 2016; Suhendri, 2012). Menurut Uno (Ranti, Budiarti, \& Trisna, 2017) kemandirian belajar adalah kemampuan untuk mengendalikan diri sendiri dalam berpikir dan bertindak, serta tidak merasa bergantung pada orang lain. Kemandirian belajar dapat meningkatkan prestasi belajar siswa dalam pendidikan matematika. Menurut Basir (Bungsu et al., 2018) kemandirian belajar adalah suatu proses pembelajaran untuk mencapai tujuan tertentu yang dituntut aktif secara individu. Kemandirian belajar harus menjadi perhatian bagi semua pihak yang berubungan dengan pendidikan (Ningsih, 2016). Kemandirian belajar berarti siswa memiliki kesadaran sendiri untuk belajar, dapat menentukan langkah-langkah yang harus di ambil, dan mampu memperoleh sumber belajar sendiri.

Ciri-ciri orang yang mempunyai kemandirian belajar yaitu: mampu berpikir secara kritis, kreatif dan inovatif, apabila ada masalah dipecahkan sendiri tanpa bantuan orang lain, dan bertanggung jawab atas pekerjaannya (Ranti et al., 2017). Faktor-faktor yang mempengaruhi kemandirian belajar yaitu: sistem pendidikan di sekolah, pola asuh orang tua, dan sistem kehidupan di masyarakat (Suid, Syafrina, \& Tursinawati, 2017). Kemandirian belajar siswa menuntut untuk siswa aktif, baik sebelum dan sesudah proses pembelajaran berlangsung.

Hasil belajar merupakan perubahan tingkah laku yang terjadi secara berkelanjutan dan tidak statis (Suhendri \& Mardalena, 2015; Suhendri, 2012). Hasil belajar juga merupakan kemampuan yang diperoleh anak setelah melalui kegiatan belajar (Lestari, 2017; Suhendri \& Mardalena, 2015). Perubahan hasil belajar tersebut dapat diartikan sebagai terjadinya peningkatan yang lebih baik. Perubahan perilaku tersebut disebabkan karena siswa sudah menguasai atas sejumlah bahan selama proses belajar. Hasil belajar juga sebagai kompetensi dan keterampilan yang akan dimiliki siswa setelah proses pembelajaran (Mølstad \& Karseth, 2016).

Hasil penelitian Utami \& Nawawi (2018) menyebutkan bahwa ada pengaruh yang signifikan kecerdasan matematis-logis dan rasa percaya diri siswa terhadap hasil belajar 
matematika. Tidak ada pengaruh kemandirian belajar terhadap hasil belajar mahasiswa (Ranti et al., 2017). Hasil penelitian juga dilakukan oleh Bungsu et al., (2018) ada pengaruh positif yang signifikan antara kemandirian belajar terhadap hasil belajar matematika. Sedangkan penelitian ini mengkaji pengaruh kecerdasan matematis-logis dan kemandirian belajar terhadap hasil belajar matematika siswa.

Pendidikan dilakukan pada lembaga pendidikan formal, yaitu di SMA Muhammadiyah 1 Malang, SMA Islam Sabilurrosyad dan SMA Islam Diponegoro. Malang. Indonesia. Berdasarkan observasi peneliti, siswa masih banyak yang bergantung kepada guru dalam hal sumber belajar. Siswa mengandalkan materi yang telah diberikan oleh guru, padahal siswa memiliki buku atau sumber belajar yang lain yang dapat di pelajari. Kemampuan siswa dalam berhitung dan logika juga masih kurang baik. Hal ini terlihat dari ketika siswa diberikan soalsoal cerita yang perlu menganalisis, siswa masih mengalami kesulitan. Siswa tidak dapat menjawab soal-soal tersebut karena tidak dapat mengidentifikasi masalah-masalah dalam soal tersebut.

Beberapa hasil penelitian menunjukan terdapat pengaruh kecerdasan matematis-logis dengan hasil belajar. Oleh karena itu, penelitian ini mencoba untuk mengetahui pengaruh kecerdasan matematis-logis dan kemandirian belajar terhadap hasil belajar. Berkaitan dengan uraian tersebut, tujuan dalam penelitian ini adalah untuk mengetahui: 1) pengaruh positif kecerdasan matematis-logis terhadap hasil belajar matematika, 2) pengaruh positif kemandirian belajar terhadap hasil belajar matematika, dan
3) pengaruh positif kecerdasan matematis-logis dan kemandirian belajar terhadap hasil belajar matematika.

\section{METODE PENELITIAN}

Jenis penelitian yang digunakan adalah penelitian ex post facto. Adapun desain dalam penelitian ini dapat dilihat pada Gambar 1.

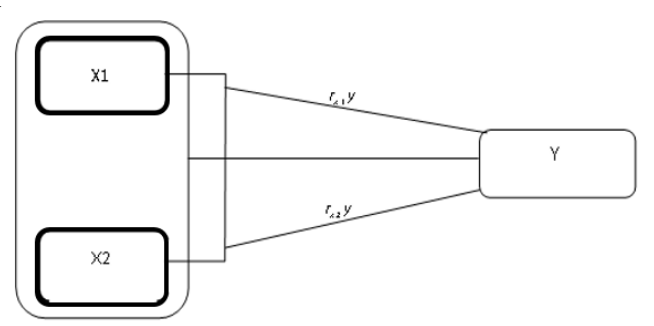

Gambar 1. Desain Penelitian

Keterangan:

$\mathrm{X}_{1}=$ kecerdasan matematis-logis

$\mathrm{X}_{2} \quad=$ kemandirian belajar

$\mathrm{Y} \quad=$ hasil belajar matematika

$\mathrm{r}_{\mathrm{x} 1 \mathrm{y}} \quad=$ hubungan variabel $\mathrm{X} 1$ dan $\mathrm{Y}$

$r_{\mathrm{x} 2 \mathrm{y}}=$ hubungan variabel $\mathrm{X} 2$ dan $\mathrm{Y}$

Penelitian ini dilakukan di beberapa sekolah Yayasan yang berada di wilayah kota Malang, diantaranya SMA Muhammadiyah Malang, SMA Islam Sabilurrosyad Karangploso dan SMA Islam Diponegoro. Penelitian ini dilaksanakan pada semester ganjil tahun pelajaran 2018/2019. Populasi dalam penelitian ini adalah siswa kelas X SMA Muhammadiyah Malang berjumlah, SMA Islam Sabilurrosyad dan SMA Islam Diponegoro. Pengambilan sampel dalam penelitian ini dilakukan dengan proportional random sampling. Pengambilan secara proporsi dilakukan dengan mengambil subjek di setiap strata. Sehingga sempel dalam penelitian ini yaitu dari SMA Muhammadiyah Malang berjumlah 100 siswa, SMA Islam Sabilurrosyad berjumlah 13 siswa dan SMA Islam Diponegoro 35 siswa, maka diperoleh 
jumlah sampel penelitian yang akan digunakan sebanyak 148 siswa.

Teknik pengumpulan data dalam penelitian ini menggunakan lembar kuesioner/angket dan tes. Lembar angket yang digunakan dalam penelitian ini terbagi menjadi dua, yaitu lembar angket kecerdasan matematislogis, dan lembar angket kemandirian belajar. Tes yang digunakan dalam penelitian ini sebagai hasil belajar matematika. Teknis analisis data dalam penelitian ini meliputi analisis data secara deskriptif dan inferensial. Analisis data yang pertama dilakukan adalah analisis statistik deskriptif. Hasil analisis statistik deskriptif yang disajikan dalam penelitian ini berupa mean, median, modus, standar deviasi, skor tertinggi, dan skor terendah. Pada analisis statistik inferensial dilakukan tahap uji hipotesis, sebelum dilakukan tahap uji tersebut dilakukan tahap uji asumsi yang terbagi atas: uji normalitas, uji multikolinearitas, dan uji heteroskedastisitas.

\section{HASIL DAN PEMBAHASAN}

\section{Data Kecerdasan Matematis-Logis}

Hasil pengumpulan data kecerdasan matematis logis dengan menggunakan instrumen angket berjumlah 148 sampel. Data selanjutnya diperoleh nilai minimum, maksimum, mean, median, modus, varians, dan standar deviasi yang ditunjukkan pada Tabel 2.

Dari Tabel 2, dapat dilihat bahwa, dari 148 responden diperoleh data nilai minimum yaitu 35 dan data maksimum 67, dengan mean dari 148 responden tersebut adalah 51,28, median 51 dan modus 49, selain itu diperoleh varians yaitu 30,001 dan standar deviasi yaitu 5,47 . Hal ini menunjukkan bahwa lebih banyak siswa yang mendapatkan nilai kecerdasan matematis-logis kurang dari
51 dan nilai kecerdasan matematis-logis tertinggi yang diperoleh yaitu 67, sedangkan hasil perhitungan data kecerdasan matematis-logis, diperoleh nilai rata-rata lebih dari median. Hal ini menunjukkan bahwa lebih banyak siswa yang mendapatkan nilai kurang dari 75 , namun hasil yang diperoleh pada data kecerdasan matematis-logis sebanyak 139 dari 148 responden atau $94 \%$ yang telah mencapai nilai ketuntasan minimal.

Tabel 2. Analisis deskriptif data kecerdasan matematis-logis.

\begin{tabular}{ccc}
\hline No & Ukuran Data & Nilai \\
\hline 1 & Minimum & 35 \\
2 & Maksimum & 67 \\
3 & Mean & 51,28 \\
4 & Median & 51 \\
5 & Modus & 49 \\
6 & Varians & 30,001 \\
7 & Standar Deviasi & 5,47 \\
\hline
\end{tabular}

Penentuan kecenderungan variabel kecerdasan matematis-logis, dengan mencari nilai rata-rata ideal (Mi) dan mencari standar deviasi ideal (SDi) Berdasarkan acuan tersebut, mean ideal variabel kecerdasan matematis logis adalah 51. Standar deviasi ideal adalah 6,4. Dari perhitungan diatas dapat dikategorikan dalam 5 kelas dan dapat dilihat pada Tabel 3.

Berdasarkan Tabel 3, diperoleh sebanyak 11 siswa atau $(7,43 \%)$ memiliki kecerdasan matematis-logis yang sangat tinggi, kecerdasan matematis-logis pada kategori tinggi sebanyak 39 siswa atau $(26,35 \%)$, kecerdasan matematis-logis pada kategori sedang 67 siswa atau $(45,27 \%)$, kecerdasan matematis-logis pada kategori rendah 28 siswa atau $(18,91 \%)$ dan yang memiliki 
kecerdasan matematis-logis pada kategori sangat rendah sebanyak 3 siswa atau $(2,02 \%)$. Hal ini menunjukkan bahwa sebagian besar siswa yang memiliki kecerdasan matematis-logis dalam kategori sedang. Sebagian kecil ada pada kategori tinggi bahkan sangat tinggi.

Tabel 3. Distribusi kategori kecerdasan matematis-logis.

\begin{tabular}{ccccc}
\hline & & \multicolumn{2}{c}{ Frekuensi } & \\
\cline { 3 - 4 } No & Skor & $\boldsymbol{F}$ & $\mathbf{\%}$ & Kategori \\
\hline 1 & $60,6<X$ & 11 & 7,43 & Sangat Tinggi \\
2 & $54,2<X \leq 60,6$ & 39 & 26,35 & Tinggi \\
3 & $47,8<X \leq 54,2$ & 67 & 45,27 & Sedang \\
4 & $41,4<X \leq 47,8$ & 28 & 18,91 & Rendah \\
5 & 41,4 & 3 & 2,02 & Sangat Rendah \\
\hline
\end{tabular}

Data Kemandirian Belajar

Hasil pengumpulan data kemandirian belajar dengan menggunakan instrumen angket berjumlah 148 responden, selanjutnya diperoleh nilai minimum, maksimum, mean, median, modus, varians, dan standar deviasi yang ditunjukkan pada Tabel 4.

Tabel 4. Analisis deskriptif data kemandirian belajar.

\begin{tabular}{ccc}
\hline No & Ukuran Data & Nilai \\
\hline 1 & Minimmum & 43 \\
2 & Maksimum & 73 \\
3 & Mean & 56,23 \\
4 & Median & 56 \\
5 & Modus & 54 \\
6 & Varians & 34,80 \\
7 & Standar Deviasi & 5,89 \\
\hline
\end{tabular}

Dari Tabel 4 dapat dilihat bahwa, dari 148 responden diperoleh data nilai minimum yaitu 43 dan data maksimum 73 , dengan mean dari 148 responden tersebut adalah 56,23, median 56, dan modus 54, selain itu di peroleh varians yaitu 34,80 dan standar deviasi yaitu 5,89 . Hal ini menunjukan bahwa lebih banyak siswa yang mendapatkan nilai kemandirian belajar di bawah 50 dan nilai kemandirian belajar tertinggi yang diperoleh yaitu 65 , sedangkan hasil perhitungan data kemandirian belajar diperoleh nilai rata-rata kurang dari nilai median. Hal ini menunjukan bahwa lebih banyak siswa mendapatkan nilai di bawah 75, namun hasil belajar yang diperoleh pada data kemandirian belajar sebanyak 145 dari 148 responden atau 98\% yang telah mencapai nilai ketuntasan minimal.

Penentuan

kecenderungan variabel kecemasan dengan mencari nilai rata-rata ideal (Mi) dan mencari standar deviasi ideal (SDi). Berdasarkan acuan tersebut, mean ideal variabel kemandirian belajar adalah 58 , Standar deviasi ideal adalah 6, Dari perhitungan diatas kemandirian belajar dikategorikan dalam 5 kelas, dapat dilihat pada Tabel 5 .

Berdasarkan Tabel 5, kemandirian belajar pada kategori sangat tinggi, sebanyak 10 siswa atau (6,75\%), kemandirian belajar pada kategori tinggi sebanyak 29 siswa atau $(19,59 \%)$, kemandirian kelajar pada kategori sedang sebanyak 48 siswa atau $(32,43 \%)$, kemandirian belajar pada kategori rendah sebanyak 48 siswa atau $(32,43 \%)$, dan kemandirian belajar pada kategori sangat rendah sebanyak 13 siswa atau (8,78\%). Hal ini 
menunjukkan bahwa sebagian besar siswa memiliki kemandirian belajar dalam kategori sedang dan rendah, sehingga dapat dikatakan kemandirian belajar siswa masih kurang.

Tabel 5. Distribusi kategori kemandirian belajar.

\begin{tabular}{lcccc}
\hline \multirow{2}{*}{ No } & \multirow{2}{*}{ Skor } & \multicolumn{2}{c}{ Frekuensi } & \multirow{2}{*}{ Kategori } \\
\cline { 3 - 4 } & & $\boldsymbol{F}$ & $\boldsymbol{\%}$ & \\
\hline 1 & $67<X$ & 10 & 6,75 & Sangat Tinggi \\
2 & $61<X \leq 67$ & 29 & 19,59 & Tinggi \\
3 & $55<X \leq 61$ & 48 & 32,43 & Sedang \\
4 & $49<X \leq 55$ & 48 & 32,43 & Rendah \\
5 & $X \leq 49$ & 13 & 8,78 & Sangat Rendah \\
\hline
\end{tabular}

Data Hasil Belajar Siswa

Pengumpulan data hasil belajar siswa diperoleh menggunakan Tes. Berdasarkan data tersebut diperoleh nilai maksimum, minimum, mean, median, modus, varians, dan standar deviasi yang ditunjukkan pada Tabel 6 . Dari Tabel 6, maka diperoleh minimum 5 dan nilai maksimum 85, dengan mean 40,07 median sebesar 35 dan Modus 30. Selain itu diperoleh varians sebesar 337,410 dan standar deviasi 18,369 . Hal ini menunjukkan bahwa hasil belajar sebagian besar siswa pada kategori sedang. Selanjutnya bisa disimpulkan bahwa sebaran dan variasi hasil belajar siswa tinggi.

Tabel 6. Analisis deskriptif data hasil belajar.

\begin{tabular}{ccc}
\hline No & Ukuran Data & Nilai \\
\hline 1 & Minimum & 5 \\
2 & Maksimum & 85 \\
3 & Mean & 40,07 \\
4 & Median & 35 \\
5 & Modus & 30 \\
6 & Varians & 337,410 \\
7 & Standar Deviasi & 18,369 \\
\hline
\end{tabular}

Pengujian Hipotesis

a) Uji Normalitas

Berdasarkan Tabel 7, hasil pengujian normalitas kolmogorov- smirnov residual regresi menggunakan SPSS 21 diperoleh nilai signifikansi kolmogorov-smirnov sebesar 0,003, dimana $0,003<0,05$ yang berarti $\mathrm{H}_{0}$ diterima, maka dapat disimpulkan bahwa regresi berdistribusi normal.

Tabel 7. Hasil uji normalitas.

\begin{tabular}{|c|c|c|}
\hline \multicolumn{3}{|c|}{ One-Sample Kolmogorov-Smirnov Test } \\
\hline & & $\begin{array}{c}\text { Unstandardized } \\
\text { Residual }\end{array}$ \\
\hline \multicolumn{2}{|l|}{$N$} & 148 \\
\hline \multirow[t]{4}{*}{ Normal Parameters } & Mean & .0000000 \\
\hline & & \\
\hline & Deviation & 18.10315708 \\
\hline & Absolute & .149 \\
\hline \multirow{2}{*}{$\begin{array}{l}\text { Most Extreme } \\
\text { Differences }\end{array}$} & Positive & .149 \\
\hline & Negatif & -.076 \\
\hline \multirow{3}{*}{\multicolumn{2}{|c|}{$\begin{array}{l}\text { Kolmogorov- } \\
\text { Smirnov } Z \\
\text { Asymp. Sig. (2- } \\
\text { tailed) }\end{array}$}} & \\
\hline & & 1.816 \\
\hline & & .003 \\
\hline
\end{tabular}

a. Test distribution is Normal.

b. Calculated from data.

b) Uji Multikolinearitas.

Berdasarkan Tabel 8, hasil pengujian multikolinearitas menggunakan SPSS 21 di peroleh nilai VIF 1,023 dimana 1 kurang dari 10, yang berarti bahwa $\mathrm{H}_{0}$ diterima dan dapat disimpulkan bahwa tidak terjadi multikolinearitas antara variabel 
kecerdasan matematis-logis dan kemandirian belajar.

c) Uji Heteroskedastisitas

$$
\text { Uji heteroskedastisitas }
$$

dilakukan dengan uji glejser dengan menggunakan SPSS 21 diperoleh nilai signifikansi untuk kecerdasan matematis-logis 0,523 dan kemandirian belajar 0,003 , dimana nilai signifikansi untuk data kecerdasan matematis-logis $0,523>0,05$, sedangkan untuk data kemandirian belajar diperoleh nilai signifikansi $0,003<0,05$. Dengan demikian dapat disimpulkan bahwa tidak terjadi gejala heteroskedastisitas untuk data kecerdasan matematis-logis dan kemandirian belajar.

Tabel 8. Hasil uji multikolinearitas.

\begin{tabular}{|c|c|c|c|c|c|c|c|c|}
\hline \multirow{3}{*}{\multicolumn{2}{|c|}{ Model }} & \multicolumn{4}{|c|}{ Coefficients $^{a}$} & \multirow{3}{*}{ Sig. } & \multirow{2}{*}{\multicolumn{2}{|c|}{$\begin{array}{l}\text { Collinearity } \\
\text { Statistics }\end{array}$}} \\
\hline & & \multicolumn{2}{|c|}{$\begin{array}{l}\text { Unstandardized } \\
\text { Coefficients }\end{array}$} & \multirow{2}{*}{$\begin{array}{c}\begin{array}{c}\text { Standardized } \\
\text { Coefficients }\end{array} \\
\text { Beta } \\
\end{array}$} & \multirow[t]{2}{*}{$t$} & & & \\
\hline & & $B$ & Std.Error & & & & Tolerance & $V I F$ \\
\hline & (Constant) & 60.417 & 18.796 & & 3.214 & .002 & & \\
\hline 1 & $\begin{array}{l}\text { KecerdasanMatematis } \\
\text { Logis }\end{array}$ & -.057 & .278 & -.017 & -.204 & .839 & .978 & 1.023 \\
\hline & Kemandirian Belajar & -.314 & .258 & -.102 & -1.220 & .224 & .978 & 1.023 \\
\hline
\end{tabular}

a. Dependent Variable: Hasil Belajar

Tabel 9. Hasil uji heteroskedastisitas.

\begin{tabular}{|c|c|c|c|c|c|c|}
\hline \multicolumn{7}{|c|}{ Coefficients $^{a}$} \\
\hline \multirow[t]{2}{*}{ Model } & & \multicolumn{2}{|c|}{$\begin{array}{c}\text { Unstandardized } \\
\text { Coefficients }\end{array}$} & \multirow{2}{*}{$\begin{array}{c}\begin{array}{c}\text { Standardized } \\
\text { Coefficients }\end{array} \\
\text { Beta } \\
\end{array}$} & \multirow[t]{2}{*}{$t$} & \multirow[t]{2}{*}{ Sig. } \\
\hline & & B & Std.Error & & & \\
\hline \multirow{3}{*}{1} & (Constant) & 45.403 & 11.069 & & 4.102 & .000 \\
\hline & KecerdasanMatematisLogis & -.105 & .163 & -.052 & -.641 & .523 \\
\hline & Kemandirian Belajar & -.457 & .152 & -.245 & -3.014 & .003 \\
\hline
\end{tabular}

a. Dependent Variable: ABSRES

\section{Uji Hipotesis}

Setelah uji asumsi terpenuhi, selanjutnya melakukan pengujian hipotesis terkait pengaruh kedua variabel bebas yaitu kecerdasan matematis-logis dan kemandirian belajar terhadap variabel terikat yaitu hasil belajar siswa, yang ditunjukkan pada Tabel 10.

Tabel 10. Hasil uji F

\section{ANOVA $^{\mathrm{a}}$}

\begin{tabular}{llrrrrr}
\hline Model & & Sum of Squares & \multicolumn{1}{c}{ df } & Mean Square & \multicolumn{1}{c}{ F } & Sig. \\
\hline \multirow{4}{*}{1} & Regression & 545.305 & 2 & 272.653 & .821 & $.442^{\mathrm{b}}$ \\
& Residual & 48175.472 & 145 & 332.245 & & \\
& Total & 48720.777 & 1477 & & & \\
\hline
\end{tabular}

a. Dependent Variable: HasilBelajar

b. Predictors: (Constant), KemandirianBelajar, KeccerdasanMatematisLogis 
Pengujian secara serentak ini
dilakukan antara
kecerdasan
matematis-logis dan kemandirian
belajar terhadap hasil belajar matematika. Berdasarkan tabel 10, hasil statistik uji $F$ pada variabel kecerdasan matematis-logis dan kemandirian Belajar diperoleh $\mathrm{F}_{\text {hitung }}$ $(0,821)$ dengan $\mathrm{db}=$ pembilang 2 dan $\mathrm{db}=$ penyebut 146 . Selain itu diperoleh nilai signifikansi $(0,442)$ lebih besar dari 0,05 sehingga $\mathrm{H}_{0}$ diterima. Maka dapat disimpulkan bahwa tidak ada pengaruh yang signifikan antara kecerdasan matematis-logis dan kemandirian belajar terhadap hasil belajar siswa.

\begin{tabular}{llr}
\multicolumn{1}{c}{ Bentuk } & \multicolumn{1}{c}{ hubungan antara } \\
kecerdasan & \multicolumn{1}{c}{ matematis-logis } & dan \\
kemandirian & belajar terhadap & hasil \\
belajar & matematika & dapat
\end{tabular}
direpresentasikan dalam persamaan atau model regresi. Berdasarkan hasil pengolahan data SPSS diperoleh nilai $b_{0}$ sebesar 60,417 nilai $b_{1}$ sebesar 0,057 dan $b_{2}$ sebesar $-0,314$. Sehingga persamaan regresi yang diperoleh untuk mempresentasikan hubungan kecerdasan matematis-logis $\left(X_{1}\right)$ dan kemandirian belajar $\left(X_{2}\right)$ terhadap hasil belajar $(Y)$ adalah sebagai berikut:

$$
Y=60,417+0,057-0,314 X_{2}+e
$$

Model tersebut menunjukkan bahwa konstanta (a) adalah 60,417 hal ini berarti jika kecerdasan matematislogis dan kemandirian belajar bernilai 0 maka indeks hasil belajar bernilai positif yaitu 60,417. Adapun nilai koefisien regresi variabel kecerdasan matematis-logis (b1) benilai negatif sebesar -0,057 hal ini dapat diartikan bahwa setiap terjadi kenaikan satusatuan dari kecerdasan matematis-logis diikuti dengan penurunan hasil belajar siswa sebesar $-0,057$ sebaliknya apabila terjadi penurunan satu satuan pada kecerdasan matematis-logis siswa akan diikuti kenaikan hasil belajar siswa sebesar -0,057. Sedangkan nilai koefisien regresi kemandirian belajar (b2) bernilai negatif sebesar $-0,314$ hal ini dapat diartikan bahwa setiap terjadi kenaikan satu satuan dari kemandirian belajar diikuti dengan kenaikan hasil belajar siswa sebesar $-0,314$ sebaliknya apabila terjadi penurunan satu satuan pada kemandirian belajar akan diikuti penurunan hasil belajar siswa sebesar 0,314 .

Hasil uji hipotesis yang pertama menunjukkan bahwa kecerdasan matematis-logis secara parsial tidak ada pengaruh signifikan terhadap hasil belajar. Hal ini dikarenakan banyak siswa memperoleh nilai kecerdasan matematis-logis yang rendah, tetapi meiliki hasil belajar dengan $94 \%$ siswa mencapai nilai ketuntasan minimal. Hasil uji hipotesis menunjukkan bahwa kecerdasan matematis-logis pada pelajaran matematika sebesar $-0,057$ yang berarti bahwa kecerdasan matematis-logis tidak ada pengaruh terhadap hasil belajar matematika. Hal ini bertolak belakang dengan penelitiannya Utami \& Nawawi, (2018) bahwa kecerdasan matematis-logis siswa mempengaruhi hasil belajar matematika. Dengan kata lain jika kecerdasan matematis-logis rendah maka hasil belajar rendah tetapi bisa juga tinggi, sebaliknya apabila kecerdasan matematis-logis tinggi maka hasil belajarnya menjadi tinggi dan bisa juga rendah.

Hasil uji hipotesis kedua menunjukkan bahwa kemandirian belajar siswa pada pembelajaran matematika secara parsial tidak ada pengaruh signifikan terhadap hasil belajar matematika. Hal ini dikarenakan banyak siswa yang 
mendapatkan nilai kemandirian belajar dibawah 50, tetapi memiliki hasil belajar dengan $98 \%$ siswa telah mencapai nilai ketuntasan minimal. Hal ini sejalan dengan penelitian Ranti et al., (2017) bahwa tidak ada pengaruh yang signifikan, yang artinya tidak ada pengaruh positif yang signifikan antara kemandirian belajar siswa terhadap hasil belajar matematika. Hal ini dikarenakan psikologi/karakter sebagian besar dari siswa dilingkungan tersebut masih minim kesadaran tentang pentingnya belajar, dan tingkat kompetitif dalam diri siswa. Sehingga tidak adanya kemandiran belajar dalam diri siswa terhadap hasil belajar yang mereka dapatkan. Penelitian ini bertolak belakang dengan (Bungsu et al., 2018) terdapat pengaruh positif yang signifikan antara kemandirian belajar terhadap hasil belajar matematika.

Hasil uji hipotesis ketiga menunjukkan bahwa kecerdasan matematis-logis dan kemandirian belajar secara bersama-sama tidak ada pengaruh yang signifikan terhadap hasil belajar siswa. Kontribusi kecerdasan matematis-logis dan kemandirian belajar secara bersamasama tidak berpengaruh signifikan terhadap hasil belajar matematika. Tidak ada pangaruh yang signifikan antara kecerdasan matematis-logis dan kemandirian belajar terhadap hasil belajar matematika. Hal ini bertolak belakang dengan hasil penelitian Rohmah \& Maknunah (2019) bahwa ada pengaruh kecerdasan matematislogis dan kemandirian belajar terhadap hasil belajar matematika siswa.

Hasil penelitian ini memberikan kontribusi teoretis bahwa kecerdasan matematis-logis dan kemandirian belajar tidak berpengaruh positif signifikan terhadap hasil belajar siswa.
Hal ini menunjukkan bahwa masih ada variabel bebas lain yang mungkin berpengaruh terhadap hasil belajar. Oleh karena itu, pada tataran praktek, guru perlu mengeksplorasi kemampuan siswa selain kecerdasan matematislogis dan kemandirian belajar untuk memaksimalkan hasil belajar siswa.

\section{KESIMPULAN DAN SARAN}

Kecerdasan matematis-logis secara parsial tidak ada pengaruh yang signifikan terhadap hasil belajar siswa. Kemandirian belajar siswa juga secara parsial tidak ada pengaruh yang signifikan terhadap hasil belajar. Tidak ada pengaruh yang signifikan kecerdasan matematis-logis dan kemandirian belajar terhadap hasil belajar matematika.

Saran bagi penelitian selanjutnya dapat mengkaji lebih mendalam dengan menambahkan variabel bebas yang lain untuk dikaitkan dengan hasil belajar siswa.

\section{DAFTAR PUSTAKA}

Bungsu, T. K., Vilardi, M., Akbar, P., \& Bernard, M. (2018). Pengaruh Kemandirian Belajar Terhadap Hasil Belajar Matematika di SMKN 1 Cihampelas. Journal On Education, 1(2), 382-389.

Lai, Y., Zhu, X., Chen, Y., \& Li, Y. (2015). Effects of Mathematics Anxiety and Mathematical Metacognition on Word Problem Solving in Children with and without Mathematical Learning Difficulties. PLoS One, 10(6), 119.

Lestari, I. (2017). Pengaruh Waktu Belajar Dan Minat Belajar Terhadap Hasil Belajar Matematika. Jurnal Formatif, 3(2), 115-125. 
Mølstad, C. E., \& Karseth, B. (2016). National Curricula In Norway And Finland: The Role Of Learning Outcomes. European Educational Research Journal, 15(3), 329-344.

Ningsih, R. (2016). Pengaruh Kemandirian Belajar Dan Perhatian Orang Tua Terhadap Prestasi Belajar Matematika. Jurnal Formatif, 6(1), 73-84.

Ranti, M. G., Budiarti, I., \& Trisna, B. N. (2017). Pengaruh Kemandirian Belajar (Self Regulated Learning) Terhadap Hasil Belajar Mahasiswa Pada Mata Kuliah Struktur Aljabar. Jurnal Pendidikan Matematika, 3(1), 75-83.

Rohmah, F. A. N., \& Maknunah, J. (2019). The Effect of Logical Mathematical Intelligence And Learning Independence On Learning Outcomes of Mathematics. Jurnal Penelitian Didaktik Matematika, 3(1), 1-14.

Suhendri, H., \& Mardalena, T. (2015). Pengaruh Metode Pembelajaran Problem Solving Terhadap Hasil Belajar Matematika. Jurnal Formatif, 3(2), 105-114.

Suid, Syafrina, A., \& Tursinawati. (2017). Analisis Kemandirian Siswa Dalam Proses Pembelajaran i Kelas III SD Negeri 1 Banda Aceh. Jurnal Pesona Dasar, 1(5), 70-81.
Sumantri, M. S., \& Satriani, R. (2016). The Effect of Formative Testing and Self- Directed Learning on Mathematics Learning Outcomes. International Electronic Journal of Elementary Education, 8(3), 507524.

Supardi. (2014). Peran Kedisiplinan Belajar Dan Kecerdasan Matematis Logis Dalam Pembelajaran Matematika. Jurnal Formatif 4(2):, 4(2), 80-88.

Triwinarni, D., Fauzi, \& Monawati. (2017). Pengaruh Kecerdasan Logika Matematika Terhadap Kedisiplinan Belajar Siswa Kelas V Sd Negeri 1 Pagar Air Kabupaten Aceh Besar. Jurnal Ilmiah Pendidikan Guru Sekolah Dasar, 2(1), 16-29.

Utami, D. S., \& Nawawi, M. (2018). Pengaruh Kecerdasan MatematisLogis Dan Rasa Percaya Diri Siswa Terhadap Hasil Belajar Matematika Kelas VIII SMPN 2 Sumbergempol. Jurnal Penelitian Pendidikan Matematika, 2(2), 92101.

Zulfairanatama, G., \& Hadi, S. (2013). Kecerdasan Logika-Matematika Berdasarkan Multiple Intelligences Terhadap Kemampuan Matematika Siswa SMP Di Banjarmasin. Jurnal Pendidikan Matematika, 1(1), 18-26. 